\title{
POLITICS IN UKRAINE
}

\section{DOI https://doi.org/10.30525/978-9934-26-181-7-15}

\author{
ПРОТИДІЯ ДЕЗІНФОРМАЦІЇ \\ БЕЗ ОБМЕЖЕННЯ СВОБОДИ СЛОВА
}

\author{
Кузьменкова К. С. \\ головний консультант відділу забезпечення діяльності членів \\ Комісії Секретаріату Центральної виборчої комісії \\ Центральна виборча комісія \\ м. Київ, Украӥна
}

Дезінформація поширюється як вітчизняними, так і іноземними суб'єктами і викликає виправдане занепокоєння з приводу іноземного втручання у вибори [3, с. 87]. Це ставить під загрозу довгострокову чесність виборів для демократій і може загрожувати самій їх основі. Дезінформація стала постійною ознакою інформації, що грунтується на увазі та керується невичерпними даними.

Спираючись на широкий спектр останніх досліджень різних аспектів дезінформації, зосередимося на правовому та теоретичному аналізі відповідей на дезінформацію 3 точки зору свободи самовираження. У міжнародному прецедентному праві щодо свободи вираження поглядів ще не було спеціально розглянуто юридичні питання, пов'язані 3 дезінформацією. Проте висновки з існуючої судової практики очевидні. 3 одного боку, передача інформації, навіть неправдивих фактів, захищена, якщо вона не порушує права інших або конкретні суспільні інтереси, такі як здоров'я, мораль або безпеку. Преса користується особливим привілеєм і в даний час навіть блогери та інші неофіційні автори можуть розглядатися як суспільні захисники. Свропейська конвенція 3 прав людини також вимагає від держав захисту права людини від обмеження приватними суб'єктами. Заходи, що обмежують поширення дезінформації, такі, як зниження пріоритету та маркування, а не видалення чи блокування, розглядаються як більше пропорційна в практиці Європейського суду з прав людини [1].

Останні дослідження показують, що дезінформація стає органічною частиною нашої інформаційної екосистеми, і боротьба з нею має бути більш тонкою [2, с. 70]. 
Дезінформація може мати руйнівний вплив на демократію і права людини. Це підриває довіру до державних інституцій, демократії та науки, руйнує демократичні цінності різноманіття, толерантність і відкритість, а також загрожує здоров'ю особи та суспільства, особливо в часи пандемії. Небезпека дезінформації серйозна і значуща, а боротьба 3 нею складна, часом суперечлива, не тільки тому, що важко знайти ефективну контрзброю, але насамперед тому, що думки та інформація (навіть неправдиві факти) користуються міцним захистом свободи вираження. Свобода вираження поглядів, свобода інформації, свобода ЗМІ та плюралізм [4].

Реакція політики на дезінформацію включає адаптацію існуючих законів і заходів політики, а також складання нових. Обидва містять ризики для свободи вираження поглядів. Однак $є$ і третій сценарій: платформи соціальних мереж займаються саморегулюванням і порушують права користувачів більше, ніж необхідно, без гарантій та судового нагляду. Ця логіка приводить до висновку, що чітке, добре продумане державне регулювання необхідне, щоб знайти ретельний баланс між ризиком дезінформації та ризику придушення, а також між державною та приватною цензурою [5].

Розглядаючи окремі фрагменти дезінформації, рекомендується, щоб вся екосистема була розглянута в цілому і зокрема онлайн-платформи як ключові учасники, які ще не регулюються. Основними цілями мають бути основні права особистості, демократія та публічний дискурс держав як виборних представників своїх громадян.

\section{Література:}

1. Турута О. Інтернет і право на свободу слова (порівняльноправовий аспект). Публічне право. 2012. № 4. URL: http:// www.yourfuture.org.ua/ua/pb/2012/8/Turuta.pdf (дата звернення: 03.12.2021).

2. Власюк О.С. Національна безпека України: еволюція проблем внутрішньої політики: вибрані наукові праці. Київ: НІСД, 2016. 528 с.

3. Фейки як інструмент впливу на вибори: аналітична доповідь. /

Дубров Д.В. та ін. Київ. 2020. 209 с.

4. The International Foundation for Electoral Systems (IFES): веб-сайт. URL: https://www.ifes.org/news/regional-europe-office-holds-successful-firstvirtual-event-light-pandemic (дата звернення: 04.12.2021).

5. Радіо Свобода: веб-сайт. URL: https://www.radiosvoboda.org/a/ news-ukraina-oon-zayava-dezinformatsiia/31337960.html (дата звернення: 05.12.2021). 